\title{
Fever in the Neurointensive Care Unit
}

\author{
Siddharth Chavali ${ }^{1, \odot}$ Manjari Tripathi ${ }^{2}$ Vanitha Rajagopalan ${ }^{1}$
}

\author{
${ }^{1}$ Department of Neuroanaesthesiology and Critical Care, All India \\ Institute of Medical Sciences (AIIMS), New Delhi, India \\ ${ }^{2}$ Department of Neurology, All India Institute of Medical Sciences \\ (AllMS), New Delhi, India
}

\begin{abstract}
Address for correspondence Manjari Tripathi, DM, Department of Neurology, Neurosciences Centre, All India Institute of Medical Sciences (AlIMS), New Delhi 110029, India (e-mail: girijarath@yahoo.co.in).
\end{abstract}

\begin{abstract}
Keywords

- fever

- hyperthermia

syndromes

- neurointensive care

Fever occurs commonly in patients admitted to the neurocritical care unit. An increase in the body temperature is known to have deleterious effects on patients with acute nervous system injury and in most cases is associated with an increase in mortality and morbidity of these patients. There are multiple causes of fever in these patients. Due to the potentially devastating effects of fever in patients with cerebral diseases, it warrants treatment in every case. In all patients with acute cerebral damage, treatment of fever and maintenance of euthermia is important to obtain a better functional recovery and to limit any further secondary insult to the brain. This review highlights the etiology and pathophysiology of fever in neurocritical care unit patients, the effects on various organ systems and associated systemic complications, and the evaluation and different therapeutic options available for the management of fever in this patient subset.
\end{abstract}

\section{Introduction}

An increase in the body temperature is often encountered in intensive care unit (ICU) patients, and is often the first sign of a more serious, potentially dangerous underlying pathology. ${ }^{1}$ There are several causes for this increase in the temperature, and it may be of infectious or noninfectious origin. Regardless of the cause, the increase in the core body temperature beyond a certain point leads to cellular, organ-specific, and systemic complications, which puts the patient at risk of increased mortality and morbidity. ${ }^{2}$ This review aims to outline the pathophysiology and etiology of fever in the neurocritical care unit.

\section{What Is Fever?}

Fever, from the Latin word febris, meaning heat, and pyrexia, from the Greek word pyr, meaning fire, is an abnormal increase in the body temperature. Normal core body temperature is often considered to be $37 \pm 1^{\circ} \mathrm{C}$ in healthy individuals., $\mathrm{An}$ increase in the temperature beyond this point is commonly encountered in intensive care practice, affecting more than two-thirds of all patients. ${ }^{5}$ Fever or pyrexia is a physiological response to stress that is regulated through pyrogenic and antipyretic pathways in the body, and is a result of an elevation in the hypothalamic set point. The term hyperthermia, although often interchanged with pyrexia, refers to a pathological process that is not associated with an increase in the hypothalamic set point. ${ }^{6}$

To establish a diagnosis of fever, a measurement of central temperature in critically ill patients to approximate core body temperature is recommended. Central measurement sites include the pulmonary artery, urinary bladder, esophagus, and rectum. Although these provide the most accurate values, in routine clinical practice, peripheral sites such as the tympanic membrane, mouth, and axilla are often used. A recent analysis showed that compared with central temperature estimation, peripheral thermometers had a sensitivity of $64 \%$ and a specificity of $96 \%$ for the detection of fever. ${ }^{7} \mathrm{~A}$ temperature greater than $38^{\circ} \mathrm{C}$ is used as the cutoff for pyrexia, ${ }^{8}$ with the caveat that a lower threshold should be employed for immunocompromised patients. Hyperthermia is usually a diagnosis of exclusion, with temperatures exceeding $41^{\circ} \mathrm{C}$, and not responsive to antipyretic medication (-Table 1).

\section{Pathophysiology}

An increase in the core body temperature is a common response to stress, and occurs via several mechanisms. The hypothalamus is the primary regulator of body temperature received

August 20, 2019

accepted after revision

September 23, 2019

published online

November 20, 2019
DOI https://doi.org/

$10.1055 / \mathrm{s}-0039-3399399$

ISSN 2348-0548.
Copyright $@ 2019$ Indian Society of Neuroanaesthesiology and Critical Care
License terms

() (1) $\ominus \circledast$ 
Table 1 Classification of fever

\begin{tabular}{|l|l|}
\hline Normal temperature & $37-38^{\circ} \mathrm{C}$ \\
\hline Low-grade fever & $38.1-39^{\circ} \mathrm{C}$ \\
\hline Moderate-grade fever & $39.1-40^{\circ} \mathrm{C}$ \\
\hline High-grade fever & $40.1-41^{\circ} \mathrm{C}$ \\
\hline Hyperpyrexia & $>41.1^{\circ} \mathrm{C}$ \\
\hline
\end{tabular}

in humans, and one of its areas-the organum vasculosum of the lamina terminalis (OVLT), located in the anterior hypothalamus at the anteroventral end of the third ventricle-is especially involved in the regulation of the febrile response. ${ }^{9}$ The OVLT is a highly vascular circumventricular structure, and as such, is devoid of the blood-brain barrier (BBB). Stimulation of the OVLT leads to release of prostanoids such as prostaglandin E2 (PGE2), which acts on the preoptic nucleus of the hypothalamus leading to lowered firing rates of warm sensitive neurons, with a net increase in the core body temperature. ${ }^{10}$ In normal conditions, decreased firing of warm sensitive neurons in cold temperatures leads to activation of heat gaining mechanisms, and prevention of heat loss via piloerection, shivering, vasoconstriction, etc.

The febrile response is believed to be a protective response to infections, ${ }^{11}$ and studies have shown that the ability to mount a febrile response may be predictive of better outcomes in infectious fever, as compared with patients who could not mount such a response. ${ }^{12}$ It is thought that elevated core body temperatures inhibit reproduction of infectious pathogens, which show optimal replication at temperatures below $37^{\circ} \mathrm{C}$. In contrast to this phenomenon, a nonpyrogenic fever is not thought to be of any physiological benefit.

\section{Effects of Fever on Miscellaneous Organ Systems}

There are several proposed mechanisms to explain the deleterious effects of a pyrexia response, some of which are as follows:

- Cellular damage Hyperthermia causes direct cellular damage, inhibiting transmembrane transport proteins and affecting membrane stability. Disruption of transmembrane ion channels leads to accumulation of intracellular calcium and sodium, leading to edema and activation of apoptotic pathways. DNA synthesis is inhibited for a sustained length of time following pyrexia, and the nuclear matrix shows damage even at $40^{\circ} \mathrm{C} . .^{13}$

- Local effects Hyperthermia leads to an increase in the levels of pro- as well as anti-inflammatory cytokines such as IL-6, IL-1, and INF, which trigger rapid changes in local organ vasculature such as capillary dilatation, stasis, and extravasation, even after approximately 30 minutes of temperatures $>40^{\circ} \mathrm{C} .{ }^{14}$

- Systemic effects are enumerated in - Table 2 and central nervous system (CNS) effects are depicted in - Fig. 1.

Excitotoxicity This is the process by which cell damage occurs as a result of excessive exposure to excitatory
Table 2 Systemic effects of fever

\begin{tabular}{|l|l|}
\hline $\begin{array}{l}\text { Gastrointestinal } \\
\text { tract }^{15,16}\end{array}$ & $\begin{array}{l}\text { Hyperthermia leads to increased gut } \\
\text { bacterial translocation, and increased } \\
\text { bowel wall permeability, which may } \\
\text { lead to an increased incidence of } \\
\text { multiorgan dysfunction-possibly due } \\
\text { to reduced GI blood flow }\end{array}$ \\
\hline Renal17 & $\begin{array}{l}\text { Hyperthermia leads to a reduced glo- } \\
\text { merular filtration rate and increased } \\
\text { concentrations of plasma urea and } \\
\text { creatinine }\end{array}$ \\
\hline Musculoskeletal & $\begin{array}{l}\text { Hyperthermia leads to rhabdomyoly- } \\
\text { sis which may exacerbate AKI }\end{array}$ \\
\hline Cardiovascular $^{18,19}$ & $\begin{array}{l}\text { Initially, hyperthermia leads to } \\
\text { increased cardiac output, possibly } \\
\text { due to vasodilation. Fragmentation of } \\
\text { myocardial fibers leads to an increase } \\
\text { in Troponin-I levels }\end{array}$ \\
\hline Hepatic ${ }^{20}$ & $\begin{array}{l}\text { At higher temperatures, ALT and AST } \\
\text { levels are found to be elevated, and } \\
\text { significant hepatocellular damage } \\
\text { may be seen }\end{array}$ \\
\hline Hemostasis ${ }^{21,22}$ & $\begin{array}{l}\text { Upto 50\% patients with hyperthermia } \\
\text { develop some form of coagulopathy, } \\
\text { demonstrating thrombocytopenia, } \\
\text { increased clotting time due to inhi- } \\
\text { bition of platelet aggregation, and } \\
\text { spontaneous bleeding }\end{array}$ \\
\hline
\end{tabular}

Abbreviations: AKI, acute kidney injury; ALT, alanine transaminase; AST, aspartate transaminase; $\mathrm{Gl}$, gastrointestinal.

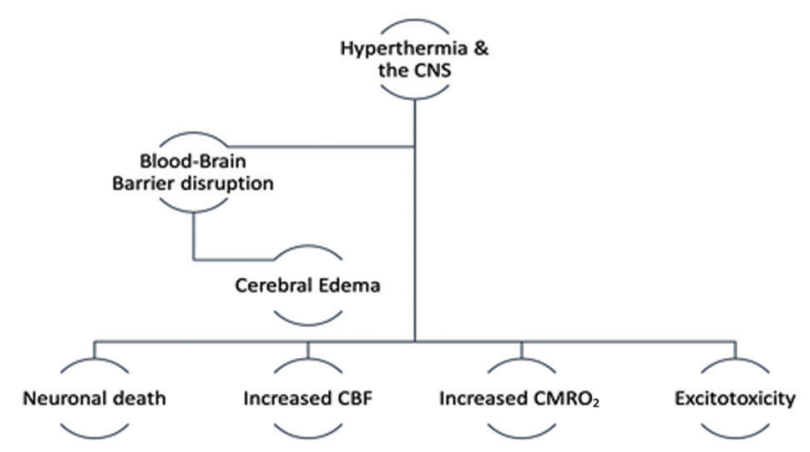

Fig. 1 Effects of hyperthermia on central nervous system.

neurotransmitters, such as glutamate and glycine, which lead to increased intraneuronal calcium influx and stimulate apoptosis. It has been seen that glutamate and glycine levels are significantly higher in hyperthermic patients with acute ischemic stroke, and the degree of hyperthermia appears to correlate with infarct size. ${ }^{23}$

Blood-brain barrier disruption Under normal conditions, the BBB is a vascular unit that consists of extremely tightly packed endothelial cells, preventing flux of large molecules into the brain. Permeability of the BBB varies with changes in temperature, allowing increased substance flux at temperatures exceeding physiological values. ${ }^{24}$ This increase in BBB permeability is thought to be the major causative factor for the development of cerebral edema in pyrexia. 
Changes in cerebral blood flow and cerebral metabolic rate $\left(\mathrm{CMRO}_{2}\right)$ Changes in both $\mathrm{CBF}$ and $\mathrm{CMRO}_{2}$ are seen with changes in the core body temperature, but the exact mechanism of these changes remains unclear. Studies have shown that $\mathrm{CBF}$ changes by approximately 6 to $7 \%$ for every $1^{\circ} \mathrm{C}$ change in the temperature, ${ }^{25}$ but $\mathrm{CBF}$ has been seen to fall below baselines when temperatures exceed $40^{\circ} \mathrm{C}$, implying uncoupling of cerebral blood flow with perfusion pressures. This uncoupling may lead to subsequent vascular dilatation and exacerbate existing intracranial hypertension, leading to increased cerebral edema.

\section{Manifestations}

Persistent neurological deficits following a sustained period of hyperthermia $>40^{\circ} \mathrm{C}$ following heat stroke have been described previously. The most common manifestation of

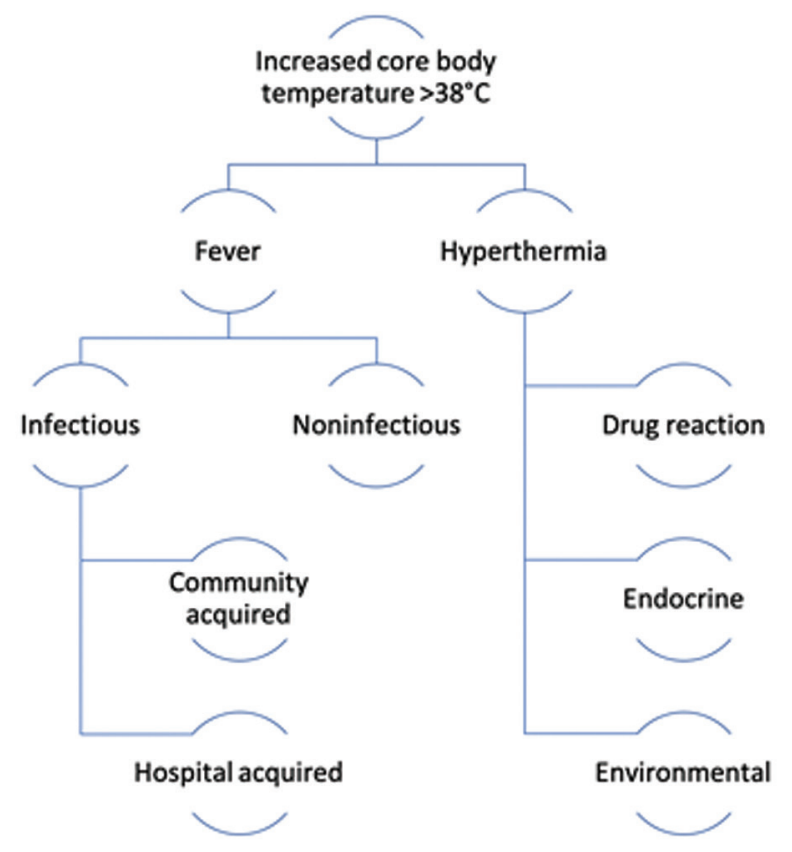

Fig. 2 Etiology of fever. persistent neurodeficit is cerebellar dysfunction, ${ }^{26}$ followed by basal ganglia dysfunction, which appears to be due to selective destruction of Purkinje cells abundant in these areas. ${ }^{27}$ Ataxia, dysarthria, and disorders of coordination may be the most common presenting symptoms. ${ }^{28}$ Damage to the cerebral cortex, brainstem, spinal cord, and peripheral nerves is unusual. Symptoms are usually bilateral, and improvement may be seen after an extended period of time, usually weeks to months.

Etiology of fever has been described as below ( - Fig. 2 ).

The differential diagnosis of fever in neuro ICU is elaborated below ( - Fig. 3 ).

\section{Infection Associated Fever}

Most episodes of fever in the intensive care setting are due to infectious causes, and are usually broadly divided into whether they are acquired within the community, or in the hospital. Hospital-acquired infections are defined as infections manifesting 48 hours or more after admission. ${ }^{29}$ Community-acquired infections are usually lower respiratory tract infections such as pneumonia and bronchitis, typically caused by Streptococcus pneumoniae, and viral pathogens. ${ }^{30}$ In contrast, hospital-acquired respiratory infections are usually ventilator-associated pneumonias (incidence around 15\%), caused by gram-negative bacilli and fungal pathogens.

Another common etiology of infectious fever is urinary tract infections. Patients admitted with urinary tract infections (UTIs) usually present with high fever and other signs of sepsis. UTI that develops in the ICU is a result of biofilm formation on indwelling urinary catheters (catheter associated urinary tract infection [CAUTI] incidence around 40-45\%), and Pseudomonas aeruginosa is the most commonly implicated organism. ${ }^{31}$ Any infection involving the urinary tract or abdomen may subsequently enter the bloodstream (incidence of 1.5-2.0\%), leading to disseminated sepsis. Risk factors for developing bloodstream infections are extremes of age, diabetes, indwelling vascular catheters (central line associated blood stream infection [CLABSI] incidence around

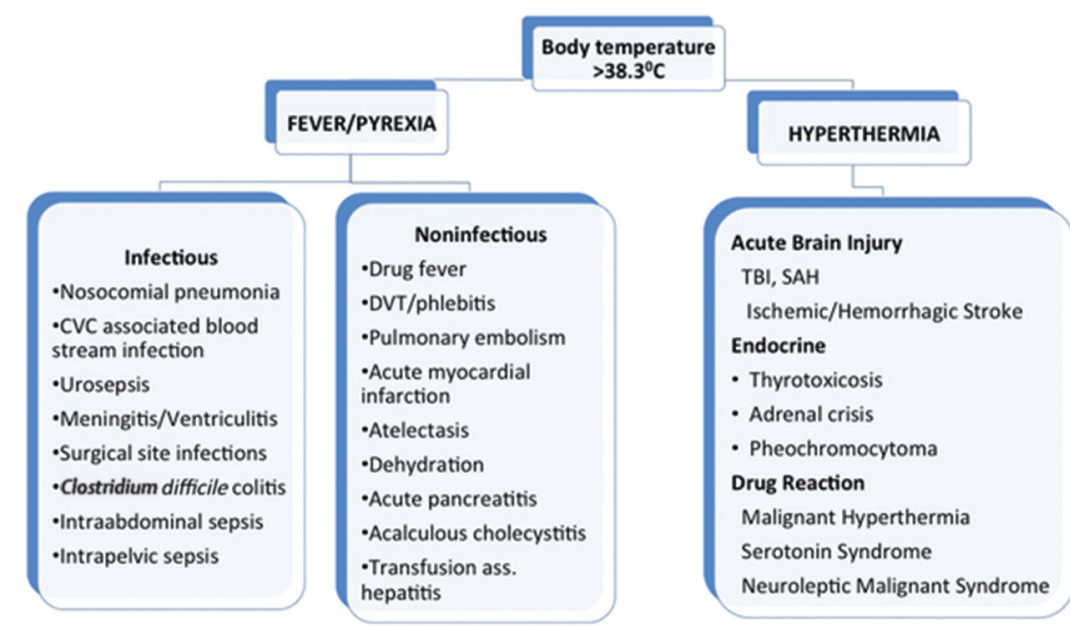

Fig. 3 Differential diagnosis of fever in neurointensive care unit. 
$10-15 \%)$, and other comorbidities such as renal failure and cancer.

An important consideration in the neurointensive care setting is fever caused by central nervous system infections, such as encephalitis, meningitis, or epidural abscesses. CNS infections have been reviewed comprehensively elsewhere, and present with the classical triad of fever, neck stiffness, and altered sensorium.

\section{Noninfectious Fever}

Unexplained fever due to noninfectious causes may be more common in the neurointensive care unit than other critical care settings. Noninfectious pyrexia has been seen to start early, less than 72 hours after admission, and may remain for several days following admission. Paroxysmal sympathetic hyperactivity (PSH) consists of periodic episodes of increased heart rate and blood pressure, sweating, hyperthermia, and motor posturing, often in response to external stimuli. It is an important cause of noninfectious fever in neurointensive care unit. It is a diagnosis of exclusion and it is important to identify the risk factors and alleviate them as it is often associated with worse outcomes.

In a study by Rabinstein et al, ${ }^{32}$ nearly one-third of patients had fever with no identifiable cause other than the primary brain injury. Fever was found to be significantly more frequent in patients with subarachnoid hemorrhage (SAH), and was associated with the development of symptomatic vasospasm. Fever has been reported in between 50 and $80 \%$ of all patients presenting with SAH within the first week, with extravasation of blood into cerebrospinal fluid (CSF) triggering the febrile response. Higher-grade SAH are associated with increased incidence of fever, which appears to be an independent predictor of mortality and morbidity in this patient population. Interestingly, maintaining euthermia following SAH has been seen to lead to improved outcomes and remains an interesting area for further research. ${ }^{33}$

In patients with traumatic brain injury (TBI), pyrexia within the first week following trauma has been seen to be associated with increased ICP, ICU stay, as well as increased mortality and morbidity. ${ }^{34}$ Aggressively instituting hypothermia in prehospital as well as intensive care settings, although of theoretical benefit, has not been seen to improve outcomes following TBI-it may actually lead to an increased rate of infections and hemodynamic complications..$^{35}$ Hence, in cases of TBI, hyperthermia needs to be corrected aggressively, but hypothermia is to be avoided.

Fever is also commonly encountered in patients with acute spinal cord injury, which is thought to be caused by thermoregulatory dysfunction. Damage to the spinal cord leads to disruption of both ascending sensory and autonomic pathways, which may manifest as impaired vasomotor responses to environmental temperature in the acute phase. ${ }^{36}$ In addition, patients with spinal cord injury are prone to other causes of noninfectious pyrexia such as deep venous thrombosis, and pulmonary embolism.

In patients presenting with acute stroke, fever appears to be an independent predictor of worse outcomes, as well as stroke severity. ${ }^{37}$ Similar to TBI, there has been an interest in the therapeutic application of hypothermia in patients with stroke for its perceived neuroprotective effects, but till date, no clinical trial has shown strong evidence to support this theory..$^{38}$ In patients with hemorrhagic stroke, persistent fever has been shown to be associated with worse outcomes. ${ }^{39}$ Hence, temperature management remains a vital part of management in patients presenting with all types of strokes.

\section{Hyperthermia Syndromes in the Neurointensive Care Unit}

These are conditions with various causative factors that terminate in fever as the common presenting symptom. The various hyperthermia syndromes are summarized as below (-Table 3).

This article will focus on the syndromes more likely to be encountered in the neurointensive care setting.

Neuroleptic malignant syndrome (NMS) is a rare and potentially lethal reaction typically associated with the use of dopamine antagonist therapy. The incidence is believed to be 0.5 to $1 \%$ of all patients treated with antipsychotics, with a range of 0.03 to $3 \%$ for patients treated with conventional antipsychotics..$^{40}$ NMS is diagnosed based on history and physical evaluation, with most patients experiencing symptoms between 14 and 30 days after exposure to a causative drug. ${ }^{41}$ The underlying mechanism is still a matter of debate, but a sudden reduction in central dopaminergic activity due to D2 receptor blockade within the nigrostriatal, hypothalamic, and cortical pathways explains the characteristic clinical triad of fever, muscle rigidity, and altered mental status. Autonomic symptoms that may occasionally accompany this disease may be explained by sympathoadrenal hyperactivity due to disorders of regulatory proteins. Typical laboratory findings include elevated creatinine phosphokinase (CPK) due to rhabdomyolysis, metabolic acidosis, and iron deficiency.

Serotonin syndrome may be triggered by the use of serotonergic drugs and overactivation of central as well as peripheral serotonin receptors-5HT-1A and 5HT-2A.42 Symptoms can occur due to therapeutic dosing, overdose, or interaction between two different serotonergic drugs acting by different mechanisms and usually begin within 24 hours of dose adjustments or alterations to drug regimen. Serotonin syndrome is characterized by autonomic hyperactivity,

Table 3 Hyperthermia syndromes in neuro intensive care unit

\begin{tabular}{|l|l|l|}
\hline $\begin{array}{l}\text { Neuroleptic } \\
\text { malignant } \\
\text { syndrome }\end{array}$ & $\begin{array}{l}\text { Serotonin } \\
\text { syndrome }\end{array}$ & $\begin{array}{l}\text { Malignant } \\
\text { catatonia }\end{array}$ \\
\hline $\begin{array}{l}\text { Anticholinergic } \\
\text { overdose }\end{array}$ & Heat stroke & $\begin{array}{l}\text { Malignant } \\
\text { hyperpyrexia }\end{array}$ \\
\hline $\begin{array}{l}\text { Parkinsonism- } \\
\text { hyperpyrexia } \\
\text { syndrome }\end{array}$ & Sepsis & Thyrotoxicosis \\
\hline
\end{tabular}


neuromuscular abnormalities such as peripheral hypertonicity and truncal rigidity, altered mental status, and fever-these form part of the Hunter Serotonin Toxicity Criteria (HSTC), when present in addition to serotonergic agent intake. ${ }^{43}$ Laboratory findings are nonspecific and include leukocytosis, low bicarbonate levels, elevated creatinine, and elevated transaminases. Serum serotonin concentrations do not appear to correlate with severity.

Malignant catatonia is a serious neuropsychiatric condition that has become less common following the use of modern antipsychotic drug therapy. It is thought that malignant catatonia and NMS follow a similar course, which involve reduced dopaminergic activity within the frontal-subcortical circuitry, suggesting that NMS may be viewed as a form of drug-induced malignant catatonia. ${ }^{44}$ The course of the disease involves progressive hyperthermia, autonomic dysfunction, impaired consciousness, and catatonia. A prodromal phase lasting approximately 2 weeks is seen in most cases, involving insomnia, anorexia, and emotional instability, followed by a phase of intense motor excitement which may be interrupted by periods of catatonia and rigidity. Electroconvulsive therapy has been described as being the preferred therapeutic modality for malignant catatonia caused by a major psychiatric illness. ${ }^{45}$

Parkinsonism hyperpyrexia syndrome is a serious complication seen following the reduction or cessation of antiparkinsonian drug therapy, especially levodopa, or other triggering factors such as intake of additional neuroleptic medication or dehydration. ${ }^{46}$ Similar to NMS, the underlying mechanism appears to be sudden suppression of central dopaminergic activity, which typically starts between 18 hours and 7 days of the triggering insult, and peaks at 72 to 96 hours. Patients become rigid and progress to an immobile state, with accompanying pyrexia, impaired consciousness, and autonomic dysfunction. Blood investigations may show leukocytosis, increased creatine kinase, and metabolic acidosis. Early identification and diagnosis are keys, and antiparkinsonian medications which have been discontinued should be administered immediately.

Drug fever, a diagnostic dilemma, can occur several days after the initiation of the drug, can take several days to subside after discontinuation of the drug, and can produce high fevers (i.e., $>38.9^{\circ} \mathrm{C}\left[102^{\circ} \mathrm{F}\right]$ ) without other signs. It is again a diagnosis of exclusion. Drug fever has multiple mechanisms, which are incompletely understood. It can be broadly classified as below ( - Table 4 ).

\section{Investigations}

A complete review of history and clinical examination are essential whenever a patient develops a new-onset fever in the ICU. Blood cultures should be sent immediately, since mortality is high without early treatment and clinical findings alone cannot exclude bacterial infection. ${ }^{47}$ The following cultures ( - Table 5) may also be indicated, based on clinical assessment.
Table 4 Classification of drug fever with the offending agents

\begin{tabular}{|c|c|}
\hline $\begin{array}{l}\text { Hypersensitivity } \\
\text { reactions }\end{array}$ & $\begin{array}{l}\text { 1. Anticonvulsants-aromatic anticon- } \\
\text { vulsants-carbamazepine, phenyto- } \\
\text { in, phenobarbital, primidone } \\
\text { 2. Minocycline } \\
\text { 3. Other antimicrobial agents- } \\
\text { beta lactams, sulfonamides, } \\
\text { nitrofurantoin } \\
\text { 4. Allopurinol } \\
\text { 5. Heparin }\end{array}$ \\
\hline $\begin{array}{l}\text { Altered ther- } \\
\text { moregulatory } \\
\text { mechanisms }\end{array}$ & $\begin{array}{l}\text { 1. Exogenous thyroid hormone } \\
\text { 2. Drugs with anticholinergic activity- } \\
\text { tricyclic antidepressants, atropine, } \\
\text { antihistamines, phenothiazines, } \\
\text { butyrophenone tranquilizers } \\
\text { 3. Sympathomimetic agents-amphet- } \\
\text { amines, cocaine }\end{array}$ \\
\hline $\begin{array}{l}\text { Reactions that are } \\
\text { directly related to } \\
\text { administration of } \\
\text { the drug }\end{array}$ & $\begin{array}{l}\text { 1. Paraldehyde } \\
\text { 2. Pentazocine } \\
\text { 3. Routine vaccinations } \\
\text { 4. Pyrogenic contamination in intrave- } \\
\text { nous fluids } \\
\text { 5. Amphotericin B } \\
\text { 6. Bleomycin }\end{array}$ \\
\hline $\begin{array}{l}\text { Reactions that are } \\
\text { direct extensions } \\
\text { of the pharmaco- } \\
\text { logic action of the } \\
\text { drug }\end{array}$ & $\begin{array}{l}\text { 1. Chemotherapy for solid tumors, } \\
\text { lymphomas, and leukemias } \\
\text { 2. Antibiotic chemotherapy-Jarisch- } \\
\text { Herxheimer reaction }\end{array}$ \\
\hline $\begin{array}{l}\text { Idiosyncratic } \\
\text { reactions }\end{array}$ & $\begin{array}{l}\text { Malignant hyperthermia } \\
\text { Neuroleptic malignant syndrome } \\
\text { Serotonin syndrome } \\
\text { Glucose-6-phosphate dehydrogenase } \\
\text { deficiency patients prescribed pri- } \\
\text { maquine, quinine, sulfonamides } \\
\text { Uncoupling oxidative phosphoryla- } \\
\text { tion-salicylate poisoning }\end{array}$ \\
\hline
\end{tabular}

Table 5 Culture and sensitivity indicated for investigation

\begin{tabular}{|l|l|}
\hline Sputum culture & $\begin{array}{l}\text { - New sputum production } \\
\text { - Change in color or volume of sputum } \\
\text { - New infiltrate on chest X-ray } \\
\text { - Increased respiratory rate } \\
\text { - Decreased oxygenation/increasing } \mathrm{FiO}_{2} \\
\text { - Increasing ventilatory support }\end{array}$ \\
\hline Urine culture & $\begin{array}{l}\text { - Indwelling urinary catheter } \\
\text { - Recent genitourinary surgery or trauma } \\
\text { - Neutropenia }\end{array}$ \\
\hline CSF culture & $\begin{array}{l}\text { - Suspected CNS infection-meningeal } \\
\text { signs, headache, and fever }\end{array}$ \\
\hline Catheter tip & $\begin{array}{l}\text { - Suspicion of catheter-related blood- } \\
\text { stream infection }\end{array}$ \\
& $\begin{array}{l}\text { - Erythema or purulence around the } \\
\text { catheter insertion site }\end{array}$ \\
\hline
\end{tabular}

Abbreviations: $\mathrm{FiO}_{2}$, inspired fraction of oxygen; CNS, central nervous system; CSF, cerebrospinal fluid. 


\section{Imaging}

Chest imaging Chest X-rays are inexpensive and easily performed at the bedside. It may help in the detection of a new or progressive pulmonary infiltrate, or identify a respiratory source of fever other than pneumonia.

Abdominal imaging Indicated for patients with a history suggestive of intra-abdominal pathology, such as recent abdominal surgery, patients with localized abdominal tenderness, palpable abdominal masses, or absent bowel sounds, and no alternative source has been identified.

Sinus evaluation Evaluation for sinusitis is appropriate for mechanically ventilated patients who have purulent nasal discharge, with no other identifiable cause for fever. Also, patients with nasogastric or orogastric tubes in situ, with periorbital edema, headache, and purulent nasal discharge, should be considered for sinus imaging.

Laboratory studies A variety of blood investigations may be ordered, based on history and clinical suspicion. In patients with abdominal pain, serum transaminases, bilirubin, alkaline phosphatase, amylase, and lipase measurements may be indicated. Thyroid-stimulating hormone (TSH), T3, and T4 levels should be drawn if thyroid storm is suspected. More specifically, if an infectious etiology of fever is suspected, apart from cultures, several biomarkers for the diagnosis of sepsis may be considered, and are tabulated below (- Table 6).

Management options may be divided broadly into pharmacological and nonpharmacological measures (-Fig. 4).

\section{Pharmacological Measures}

The primary site of action of antipyretic medications is the hypothalamic thermoregulatory center. Through their action on cyclooxygenase (COX) enzymes involved in the arachidonic acid pathway, these drugs inhibit the synthesis of endogenous pyrogenic substances such as prostaglandin E2, which are released in response to inflammation and other physiological stress. ${ }^{54}$

Acetaminophen is a peripheral COX enzyme inhibitor that is metabolized by cytochrome p450. This in turn inhibits cyclooxygenase activity and demonstrates strong antipyretic properties. It is metabolized in the liver and caution should be exercised in patients with underlying hepatic dysfunction. Ibuprofen is a nonsteroidal anti-inflammatory (NSAID) agent that has antipyrexial properties, although its effects on patients with acute brain injury need further evaluation..$^{55} \mathrm{~A}$ study demonstrated that infusion of diclofenac sodium, another NSAID medication, was effective at reducing fever in patients with acute brain injury without increase in the incidence of adverse effects. ${ }^{56}$

There are conflicting data about the use of antipyretics in febrile ICU patients-administration of NSAIDs or acetaminophen for fever control in septic patients was associated with

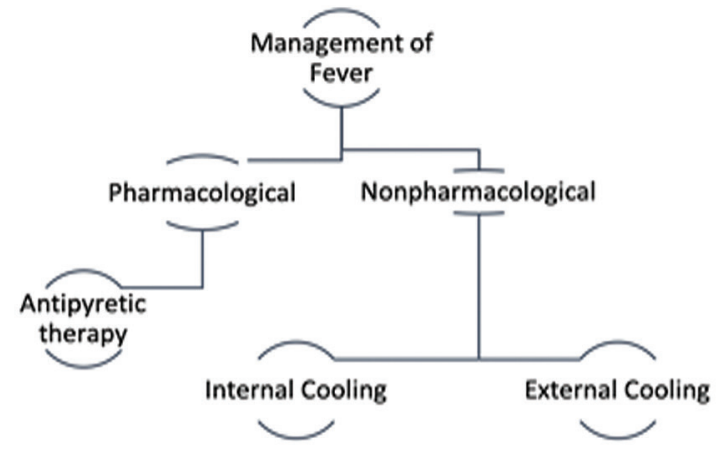

Fig. 4 Management options for fever.

Table 6 Laboratory studies performed for investigation of fever

\begin{tabular}{|c|c|c|c|}
\hline Test & Rationale & Advantage & Disadvantage \\
\hline C-reactive protein ${ }^{48}$ & $\begin{array}{l}\text { - Complement activator, macro- } \\
\text { phage activator }\end{array}$ & $\begin{array}{l}\text { - Inexpensive } \\
\text { - Widely available } \\
\text { - Rapid decrease in serial levels, } \\
\text { may indicate response to } \\
\text { therapy }\end{array}$ & $\begin{array}{l}\text { - Nonspecific } \\
\text { - May not distinguish } \\
\text { between infectious and } \\
\text { noninfectious causes }\end{array}$ \\
\hline $\begin{array}{l}\text { Erythrocyte sedimenta- } \\
\text { tion rate }(E S R)^{49}\end{array}$ & $\begin{array}{l}\text { Increases with inflammation, } \\
\text { due to increased levels of } \\
\text { fibrinogen }\end{array}$ & $\begin{array}{l}\text { - Inexpensive } \\
\text { - Widely available }\end{array}$ & $\begin{array}{l}\text { - Nonspecific } \\
\text { - Affected by multiple } \\
\text { pathologies }\end{array}$ \\
\hline Procalcitonin (PCT) $)^{50,51}$ & $\begin{array}{l}\text { - Synthesized by parafollicular } \\
\text { C cells in thyroid, but also } \\
\text { produced in the lungs and GIT } \\
\text { during sepsis }\end{array}$ & $\begin{array}{l}\text { - Levels peak rapidly after expo- } \\
\text { sure to endotoxins } \\
\text { - Can distinguish between bac- } \\
\text { terial and noninfectious causes } \\
\text { - Rapid results }\end{array}$ & $\begin{array}{l}\text { - Expensive } \\
\text { - No consensus regarding } \\
\text { cutoff values } \\
\text { - Questionable value in } \\
\text { diagnosis of fungal or viral } \\
\text { disease }\end{array}$ \\
\hline Proadrenomedullin ${ }^{52,53}$ & $\begin{array}{l}\text { - Produced from the same } \\
\text { molecule as adrenomedul- } \\
\text { lin, which is a vasodilator } \\
\text { produced during physiological } \\
\text { stress by a variety of tissues }\end{array}$ & $\begin{array}{l}\text { - Can distinguish sepsis from } \\
\text { SIRS } \\
\text { - Levels increase even in local- } \\
\text { ized infections } \\
\text { - Predictive of mortality }\end{array}$ & $\begin{array}{l}\text { - Expensive } \\
\text { - Not widely available }\end{array}$ \\
\hline
\end{tabular}


increased 28-day mortality in one study, ${ }^{57}$ while another study showed that patients receiving acetaminophen had lower in-hospital mortality (10 vs. $20 \%$ ) than those who did not. ${ }^{58}$ Another recent study of critically ill patients with fever thought to be secondary to infection reported that compared with placebo, IV acetaminophen administered until resolution of fever, cessation of antibiotics, ICU discharge, or death did not increase the number of ICU-free days. ${ }^{59}$ In addition, mortality was unaffected by acetaminophen. If antipyretic therapy is deemed to be necessary, acetaminophen rather than NSAIDs appears to be preferred by most clinicians.

\section{Nonpharmacological Measures}

External cooling can be used to reduce body temperature by enhancing core body heat loss. ${ }^{60}$ Hyperthermia is generally most effectively managed by external cooling methods employing evaporation and convection. The ability of this modality to lower core temperature in febrile patients may be limited, since it causes cutaneous vasoconstriction as well as shivering. When cutaneous vasoconstriction is induced, reduction in cutaneous heat loss may lead to core body temperature being maintained.

Shivering not only impedes the cooling process, it also imposes an additional metabolic load on the patient-doubling oxygen consumption, increasing carbon dioxide production, and stimulating the sympathetic nervous system. To avoid this, attempts to suppress the shivering response by administration of various sedative, analgesics, and anesthetic medications may be used. ${ }^{61}$

Regarding evidence for the use of external cooling, in a trial of external cooling in patients with septic shock, reduction in vasopressor consumption and 14-day mortality was seen in the intervention group (19 vs. 34\%) although this difference in the outcome was not sustained. ${ }^{62}$

Internal cooling refers to the infusion of chilled intravenous fluids to directly reduce the core body temperature. An intravenous infusion of $20 \mathrm{~cm}^{3} / \mathrm{kg}$ of normal saline at a temperature of $4^{\circ} \mathrm{C}$ is typically infused over approximately 15 minutes, and leads to a drop in core temperature by approximately $1^{\circ} \mathrm{C} .^{63}$ However, this technique should be employed with caution, as patients with a history of cardiac dysfunction are at risk of circulatory overload. Cooled intravenous fluids have been studied, but there is no clear consensus on their benefit (preservation of neurologic function) versus potential harm (induced shivering). Several ongoing trials may help clarify the role of antipyretics and cooling in critically ill patients with hyperthermia. However, until these data are available, there appears to be a minimal role for routine treatment of fever with either antipyretics or external cooling. ${ }^{64}$

Common concerns whenever a patient develops a new fever in the ICU is whether or not empiric antibiotic therapy is to be instituted and intravascular catheters need to be removed. In patients with suspected sepsis or septic shock, there is literature to suggest that reduced time to antibiotic administration is associated with lower mortality rates. ${ }^{47,65}$
There is also evidence that antibiotic administration leads to a reduction in mortality in patients who present with neutropenia and fever. ${ }^{66}$ Routinely removing invasive monitoring devices such as central venous catheters in febrile patients is a controversial issue. Severity of illness, age of the catheter, and probability that the catheter is the source of fever need to be considered before a decision is made.

\section{Conclusion}

Whether caused by pyrexia or hyperthermia syndrome, an increase in the core body temperature is frequently encountered in the intensive care setting. Current evidence suggests that pyrexia is most frequently caused by infectious etiologies although in patients with acute neurological illnesses, early fever may also indicate a noninfectious process. Further data are needed to ascertain whether aggressive intervention in febrile patients leads to limitation of secondary brain injury.

\section{Conflict of Interest}

None declared.

\section{References}

1 Circiumaru B, Baldock G, Cohen J. A prospective study of fever in the intensive care unit. Intensive Care Med 1999;25(7):668-673

2 Laupland KB, Shahpori R, Kirkpatrick AW, Ross T, Gregson DB, Stelfox HT. Occurrence and outcome of fever in critically ill adults. Crit Care Med 2008;36(5):1531-1535

3 Wunderlich CA. Das Verhalten der Eigenwärme in Krankheiten Leipzig, Germany: O. Wigand; 1870

4 Mackowiak PA, Wasserman SS, Levine MM. A critical appraisal of 98.6 degrees F, the upper limit of the normal body temperature, and other legacies of Carl Reinhold August Wunderlich. JAMA 1992;268(12):1578-1580

5 Rincon F, Hunter K, Schorr C. Dellinger RP, Zanotti-Cavazzoni $\mathrm{S}$. The epidemiology of spontaneous fever and hypothermia on admission of brain injury patients to intensive care units: a multicenter cohort study. J Neurosurg 2014;121(4):950-960

6 Denborough M. Malignant hyperthermia. Lancet 1998;352 (9134):1131-1136

7 Niven DJ, Gaudet JE, Laupland KB, Mrklas KJ, Roberts DJ, Stelfox HT. Accuracy of peripheral thermometers for estimating temperature: a systematic review and meta-analysis. Ann Intern Med 2015;163(10):768-777

8 Egi M, Morita K. Fever in non-neurological critically ill patients: a systematic review of observational studies. J Crit Care 2012;27(5):428-433

9 Boulant JA. Role of the preoptic-anterior hypothalamus in thermoregulation and fever. Clin Infect Dis 2000;31(Suppl 5):S157-S161

10 Saper CB, Breder CD. The neurologic basis of fever. N Engl J Med 1994;330(26):1880-1886

11 Evans SS, Repasky EA, Fisher DT. Fever and the thermal regulation of immunity: the immune system feels the heat. Nat Rev Immunol 2015;15(6):335-349

12 Ahkee S, Srinath L, Ramirez J. Community-acquired pneumonia in the elderly: association of mortality with lack of fever and leukocytosis. South Med J 1997;90(3):296-298

13 Roti Roti JL. Cellular responses to hyperthermia (40-46 degrees C): cell killing and molecular events. Int J Hyperthermia 2008;24(1):3-15 
14 Bouchama A, al-Sedairy S, Siddiqui S.,. Shail E, Rezeig M. Elevated pyrogenic cytokines in heatstroke. Chest 1993;104(5):1498-1502

15 Lambert GP. Role of gastrointestinal permeability in exertional heatstroke. Exerc Sport Sci Rev 2004;32(4):185-190

16 Hall DM, Buettner GR, Oberley LW, Xu L, Matthes RD, Gisolfi $\mathrm{CV}$. Mechanisms of circulatory and intestinal barrier dysfunction during whole body hyperthermia. Am J Physiol Heart Circ Physiol 2001;280(2):H509-H521

17 Mustafa S, Elgazzar AH, Essam H, Gopinath S, Mathew M. Hyperthermia alters kidney function and renal scintigraphy. Am J Nephrol 2007;27(3):315-321

18 Atar S, Rozner E, Rosenfeld T. Transient cardiac dysfunction and pulmonary edema in exertional heat stroke. Mil Med 2003;168(8):671-673

19 Vlad M, Ionescu N, Ispas AT, Giuvărăşteanu I, Ungureanu E, Stoica C. Morphological changes during acute experimental short-term hyperthermia. Rom J Morphol Embryol 2010;51(4):739-744

20 Alzeer AH, el-Hazmi MA, Warsy AS, Ansari ZA, Yrkendi MS. Serum enzymes in heat stroke: prognostic implication. Clin Chem 1997;43(7):1182-1187

21 Dematte JE, O'Mara K, Buescher J, et al. Near-fatal heat stroke during the 1995 heat wave in Chicago. Ann Intern Med 1998;129(3):173-181

22 Etulain J, Lapponi MJ, Patrucchi SJ, et al. Hyperthermia inhibits platelet hemostatic functions and selectively regulates the release of alpha-granule proteins. J Thromb Haemost 2011;9(8):1562-1571

23 Castillo J, Dávalos A, Noya M. Aggravation of acute ischemic stroke by hyperthermia is related to an excitotoxic mechanism. Cerebrovasc Dis 1999;9(1):22-27

24 Kiyatkin EA, Sharma HS. Permeability of the blood-brain barrier depends on brain temperature. Neuroscience 2009;161(3):926-939

25 Nemoto EM, Frankel HM. Cerebral oxygenation and metabolism during progressive hyperthermia. Am J Physiol 1970;219(6):1784-1788

26 Yaqub BA. Neurologic manifestations of heatstroke at the Mecca pilgrimage. Neurology 1987;37(6):1004-1006

27 Bazille C, Megarbane B, Bensimhon D, et al. Brain damage after heat stroke. J Neuropathol Exp Neurol 2005;64(11):970-975

28 Laxe S, Zúniga-Inestroza L, Bernabeu-Guitart M. [Neurological manifestations and their functional impact in subjects who have suffered heatstroke]. Rev Neurol 2013;56(1):19-24

29 Horan TC, Gaynes RP. Surveillance of nosocomial infections. In: Mayhall CG, ed. Hospital Epidemiology and Infection Control. Philadelphia: Lippincott Williams and Wilkins; 2004:1659-1702

30 Jain S, Self WH, Wunderink RG, et al; CDC EPIC Study Team. Community-acquired pneumonia requiring hospitalization among U.S. adults. N Engl J Med 2015;373(5):415-427

31 Bagshaw SM, Laupland KB. Epidemiology of intensive care unit-acquired urinary tract infections. Curr Opin Infect Dis 2006;19(1):67-71

32 Rabinstein AA, Sandhu K. Non-infectious fever in the neurological intensive care unit: incidence, causes and predictors. J Neurol Neurosurg Psychiatry 2007;78(11):1278-1280

33 Badjatia N, Fernandez L, Schmidt JM, et al. Impact of induced normothermia on outcome after subarachnoid hemorrhage: a case-control study. Neurosurgery 2010;66(4):696-700, discussion 700-701

34 Andrews PJD, Sleeman DH, Statham PFX, et al. Predicting recovery in patients suffering from traumatic brain injury by using admission variables and physiological data: a comparison between decision tree analysis and logistic regression. J Neurosurg 2002;97(2):326-336
35 Cooper DJ, Nichol AD, Bailey M, et al; POLAR Trial Investigators and the ANZICS Clinical Trials Group. Effect of early sustained prophylactic hypothermia on neurologic outcomes among patients with severe traumatic brain injury: the POLAR randomized clinical trial. JAMA 2018;320(21):2211-2220

36 Krassioukov AV, Karlsson A-K, Wecht JM, Wuermser LA, Mathias CJ, Marino RJ; Joint Committee of American Spinal Injury: Association and International Spinal Cord Society. Assessment of autonomic dysfunction following spinal cord injury: rationale for additions to International Standards for Neurological Assessment. J Rehabil Res Dev 2007;44(1):103-112

37 Wang Y, Lim LL, Levi C, Heller RF, Fisher J. Influence of admission body temperature on stroke mortality. Stroke 2000;31(2):404-409

38 den Hertog HM, van der Worp HB, van Gemert HMA, et al. PAIS Investigators. The Paracetamol (Acetaminophen) In Stroke (PAIS) trial: a multicentre, randomised, placebo-controlled, phase III trial. Lancet Neurol 2009;8(5):434-440

39 Schwarz S, Häfner K, Aschoff A, Schwab S. Incidence and prognostic significance of fever following intracerebral hemorrhage. Neurology 2000;54(2):354-361

40 Pelonero AL, LevensonJL, Pandurangi AK. Neuroleptic malignant syndrome: a review. Psychiatr Serv 1998;49(9):1163-1172

41 Caroff SN, Mann SC. Neuroleptic malignant syndrome. Psychopharmacol Bull 1988;24(1):25-29

42 Volpi-Abadie J, Kaye AM, Kaye AD. Serotonin syndrome. Ochsner J 2013;13(4):533-540

43 Dunkley EJC, Isbister GK, Sibbritt D, Dawson AH, Whyte IM. The Hunter Serotonin Toxicity Criteria: simple and accurate diagnostic decision rules for serotonin toxicity. QJM 2003;96(9):635-642

44 Northoff G. Catatonia and neuroleptic malignant syndrome: psychopathology and pathophysiology. J Neural Transm (Vienna) 2002;109(12):1453-1467

45 Luchini F, Medda P, Mariani MG, Mauri M, Toni C, Perugi G. Electroconvulsive therapy in catatonic patients: efficacy and predictors of response. World J Psychiatry 2015;5(2):182-192

46 Newman EJ, Grosset DG, Kennedy PGE. The parkinsonism-hyperpyrexia syndrome. Neurocrit Care 2009;10(1):136-140

47 Gaieski DF, Mikkelsen ME, Band RA, et al. Impact of time to antibiotics on survival in patients with severe sepsis or septic shock in whom early goal-directed therapy was initiated in the emergency department. Crit Care Med 2010;38(4):1045-1053

48 Póvoa P, Almeida E, Moreira P, et al. C-reactive protein as an indicator of sepsis. Intensive Care Med 1998;24(10):1052-1056

49 Zacharski LR, Kyle RA. Significance of extreme elevation of erythrocyte sedimentation rate. JAMA 1967;202(4):264-266

50 Bouadma L, Luyt CE, Tubach F, et al. PRORATA trial group. Use of procalcitonin to reduce patients' exposure to antibiotics in intensive care units (PRORATA trial): a multicentre randomised controlled trial. Lancet 2010;375(9713):463-474

51 Delèvaux I, André M, Colombier M, et al. Can procalcitonin measurement help in differentiating between bacterial infection and other kinds of inflammatory processes? Ann Rheum Dis 2003;62(4):337-340

52 Struck J, Tao C, Morgenthaler NG, Bergmann A. Identification of an Adrenomedullin precursor fragment in plasma of sepsis patients. Peptides 2004;25(8):1369-1372

53 Al Shuaibi M, Bahu RR, Chaftari AM, et al. Pro-adrenomedullin as a novel biomarker for predicting infections and response to antimicrobials in febrile patients with hematologic malignancies. Clin Infect Dis 2013;56(7):943-950

54 Vane JR. Inhibition of prostaglandin synthesis as a mechanism of action for aspirin-like drugs. Nat New Biol 1971;231(25):232-235

55 Dippel DWJ, van Breda EJ, van der Worp HB, et al. PISA-Investigators. Effect of paracetamol (acetaminophen) and 
ibuprofen on body temperature in acute ischemic stroke PISA, a phase II double-blind, randomized, placebo-controlled trial [ISRCTN98608690]. BMC Cardiovasc Disord 2003;3:2

56 Cormio M, Citerio G. Continuous low dose diclofenac sodium infusion to control fever in neurosurgical critical care. Neurocrit Care 2007;6(2):82-89

57 Lee BH, Inui D, Suh GY, et al. Fever and Antipyretic in Critically ill patients Evaluation (FACE) Study Group. Association of body temperature and antipyretic treatments with mortality of critically ill patients with and without sepsis: multi-centered prospective observational study. Crit Care 2012;16(1):R33

58 Suzuki S, Eastwood GM, Bailey M, et al. Paracetamol therapy and outcome of critically ill patients: a multicenter retrospective observational study. Crit Care 2015;19:162

59 Young P, Saxena M, Bellomo R, et al; HEAT Investigators; Australian and New Zealand Intensive Care Society Clinical Trials Group. Acetaminophen for fever in critically ill patients with suspected infection. N Engl J Med 2015;373(23):2215-2224

60 Axelrod P. External cooling in the management of fever. Clin Infect Dis 2000;31(5, Suppl 5):S224-S229
61 Choi HA, Ko S-B, Presciutti M, et al. Prevention of shivering during therapeutic temperature modulation: the Columbia anti-shivering protocol. Neurocrit Care 2011;14(3):389-394

62 Schortgen F, Clabault K, Katsahian S, et al. Fever control using external cooling in septic shock: a randomized controlled trial. Am J Respir Crit Care Med 2012;185(10):1088-1095

63 Fink EL, Kochanek PM, Clark RSB, Bell MJ. Fever control and application of hypothermia using intravenous cold saline. Pediatr Crit Care Med 2012;13(1):80-84

64 Gozzoli V, Schöttker P, Suter PM, Ricou B. Is it worth treating fever in intensive care unit patients? Preliminary results from a randomized trial of the effect of external cooling. Arch Intern Med 2001;161(1):121-123

65 Kumar A, Roberts D, Wood KE, et al. Duration of hypotension before initiation of effective antimicrobial therapy is the critical determinant of survival in human septic shock. Crit Care Med 2006;34(6):1589-1596

66 Viscoli C, Varnier O, Machetti M. Infections in patients with febrile neutropenia: epidemiology, microbiology, and risk stratification. Clin Infect Dis 2005;40(Suppl 4):S240-S245 